\title{
Microlavage: a technique for determining the volume of epithelial lining fluid
}

\author{
David R Baldwin, Richard Wise, Jennifer M Andrews, David Honeybourne
}

\begin{abstract}
A new technique ("microlavage") was used to determine the volume of epithelial lining fluid recovered by bronchoalveolar lavage. A standard bronchial brush tube is used to lavage a peripheral lung subsegment rapidly with $20 \mathrm{ml}$ of normal saline and the concentrations of urea and total protein are measured in the aspirated fluid. Using a very short dwell time for fluid (less than 20 seconds), this technique allows the urea dilution method to be used to quantify the epithelial lining fluid protein concentration, which is then used as an endogenous marker of the epithelial lining fluid in conventional bronchoalveolar lavage fluid. The reproducibility of the calculation of the concentration of the lining fluid protein was assessed in 10 patients by performing the method in three separate lung subsegments. The mean coefficient of variation of the urea to protein ratio was $9 \cdot 0 \%$. A comparison of microlavage and conventional lavage was made in a further 28 patients. The differential cell counts were similar by the two methods, suggesting that similar epithelial lining fluid was sampled. The application of the microlavage technique to the calculation of epithelial lining fluid volume gave a lower value than the urea dilution method in association with conventional lavage. Microlavage should provide more accurate quantification of epithelial lining fluid volume and could be used in conjunction with conventional lavage, which is still required for an adequate harvest of alveolar cells.
\end{abstract}

Bronchoalveolar lavage is an established technique for sampling the cells and lining fluid of the distal airways and alveoli, and has provided useful insights into host defences and the pathogenesis of various pulmonary diseases. ${ }^{12}$ For making comparisons between patients with disease and control subjects, the proportion of lavage fluid which represents the epithelial lining fluid must be determined. This enables the concentrations of various constituents of the lining fluid to be calculated. Methodological difficulties with the calculation of lining fluid volume have led many workers to quote concentrations of constituents as percentages of protein or albumin in the bronchoalveolar lavage fluid. ${ }^{1-3}$ Unfortunately, the albumin and protein concentra- tions of epithelial lining fluid are unknown and are likely to vary in disease states as a result of changes in alveolar-blood barrier permeability or of inflammatory cell infiltration. Standardisation of lavage techniques have been recommended so that the findings of different research groups may be compared. ${ }^{4-6}$ There are still likely to be wide variations in the volume of lining fluid recovered, even by the same operator, so quantification of the lining fluid volume is essential for comparisons to be valid. One method to be reported was based on the fact that urea, by virtue of its small molecular weight and relatively non-polar nature, travels across membranes easily, and therefore exists in the same concentration in the lining fluid as in blood. ${ }^{7}$ Urea recovered in the lavage fluid was used to calculate the volume as follows:

Epithelial lining fluid volume =

$$
\frac{\text { lavage fluid volume } \times \text { lavage [urea] }}{\text { Epithelial lining fluid [urea }} \text {, }
$$

where the square brackets denote concentration and the asterisk blood urea. This method has been shown to overestimate the lining fluid volume because urea diffuses from the interstitium and blood to produce an approximately $100 \%$ increase in lavage fluid urea concentration after a five minute dwell time. ${ }^{78}$ Shorter dwell times would theoretically eliminate this problem but necessitate the use of smaller volumes of instillate, which do not lavage distal airways because the bronchoscope is wedged proximally. ${ }^{59}$ A technique that enables rapid lavage of distal airways is needed for application of the urea method. The total protein concentration of the lining fluid could then be calculated and, because total protein does not vary with lavage dwell time, ${ }^{8}$ total protein of the lining fluid could then be used as an endogenous marker of lining fluid in conventional lavage fluid. The assumption is made that similar lining fluid is sampled by the two lavage methods.

The aims of the present study were: (1) to develop a technique for peripheral airway lavage; (2) to assess the reproducibility of the calculation of the total protein concentration in epithelial lining fluid; (3) to compare the technique with conventional lavage to ensure that similar epithelial lining fluid was sampled by the two techniques; and (4) to quantify the overestimation of lining fluid volume made when the urea dilution method is applied directly to the fluid recovered by conventional lavage. 


\section{Methods}

DEVELOPMENT OF PERIPHERAL LAVAGE IN POSTMORTEM LUNGS

Ten normal postmortem lungs were used to establish the volume of instillate required to ensure complete filling of a distal lung subsegment, the time required for lavage, and the best method for obtaining an adequate aspirate. The right middle lobe and lingular segmental orifices were identified. The segments were then inflated with air by means of a tightly fitting tube with a syringe and three way tap. A standard bronchial brush tube was then passed gently along a middle lobe or lingular orifice until it was wedged. Methylene blue dye was injected, the pleural surface observed for staining, and the time necessary for aspirating a small sample noted.

\section{REPRODUCIBILITY}

Reproducibility was measured by performing microlavage in three subsegments in 15 patients undergoing fibreoptic bronchoscopy for diagnostic purposes. The final diagnosis in these patients was haemoptysis (no cause found) in four, chronic airflow limitation in five, lung cancer in three, and focal radiographic abnormality (no cause identified at bronchoscopy) in three. Their mean age was 70 (range 58-87) years. For bronchoscopy standard premedication was used, with $0.6 \mathrm{mg}$ intramuscular atropine, $160 \mathrm{mg}$ nebulised $4 \%$ lignocaine, and 2-7 mg intravenous midazolam. For each patient the urea to protein ratio was calculated for each microlavage specimen. This ratio determines the epithelial lining fluid protein concentration as the blood urea concentration is a constant for the period of bronchoscopy.

The protein concentration of the lining fluid obtained by microlavage was calculated as follows:

Epithelial lining fluid volume =

$$
\frac{\text { [urea] lavage } \times \text { volume lavage }}{\text { [urea] blood }}
$$

Epithelial lining fluid [protein] = volume lavage $\times$ [protein] lavage

Epithelial lining fluid volume

Epithelial lining fluid [protein] = $\underline{\text { [protein] lavage } \times \text { [urea] blood }}$ [urea] lavage

The third equation applies to microlavage only.

\section{COMPARISON WITH CONVENTIONAL LAVAGE}

In 28 patients (21 male) undergoing diagnostic fibreoptic bronchoscopy as outlined above microlavage and conventional lavage were performed. The patients had a mean age of 62 (range 28-78) years and the final diagnosis was haemoptysis (no cause found) in five, chronic airflow limitation in seven, lung cancer in seven, and radiographic abnormalities in 10 (suspicious hilar opacity in four and peripheral opacity of unknown cause in six).

\section{Microlavage}

After careful examination of the airways, and before any diagnostic specimens were taken, a standard $1.7 \mathrm{~mm}$ diameter bronchial brush tube was inserted into the biopsy channel. The tube was positioned into the right middle lobe or lingula having first been flushed with normal saline in the opposite main bronchus to remove any contamination derived from the biopsy channel. The tube was then gently wedged into a distal lung segment, and $20 \mathrm{ml}$ warm saline was injected. The bronchoscope was then held still, the tube was withdrawn $1 \mathrm{~cm}$, and gentle aspiration was performed.

\section{Conventional lavage}

Following this, a standard lavage procedure was performed in a different lung subsegment, using four $50 \mathrm{ml}$ aliquots. The aspirate from the first $50 \mathrm{ml}$ aliquot was discarded. ${ }^{9}$ Samples were collected by gentle suction into a $150 \mathrm{ml}$ polycarbonate trap. Lavage time was limited to four minutes.

\section{QUANTIFICATION OF THE OVERESTIMATE OF} EPITHELIAL LINING FLUID VOLUME WHEN THE UREA DILUTION METHOD IS APPLIED DIRECTLY TO FLUID RECOVERED BY CONVENTIONAL LAVAGE The volumes of fluid recovered by microlavage and conventional lavage and the total protein and urea concentrations in blood were used to calculate the volume of lining fluid recovered by conventional lavage by two methods:

\section{Conventional urea method}

Conventional lavage specimen:

Volume of epithelial lining fluid =

$$
\frac{\text { lavage volume } \times \text { lavage [urea] }}{\text { epithelial lining fluid [urea] }} \text {. }
$$

Use of microlavage

Microlavage sample:

Epithelial lining fluid [protein] $=$

$$
\text { epithelial lining fluid [urea] } \times \text { microlavage }
$$
[protein]

$$
\text { microlavage [urea] }
$$

Conventional lavage sample:

Volume of epithelial lining fluid =

$$
\frac{\text { lavage volume } \times \text { lavage [total protein] }}{\text { epithelial lining fluid [total protein] }} .
$$

\section{Sample processing}

Both samples were transferred into teflon containers and a total cell count preparation was made with an Improved Neubauer haemocytometer. The total white cell and red cell counts were estimated. Samples were excluded from analysis if the red cell count was greater than $400 \times 10^{6} / 1$. The samples were immediately centrifuged at $400 \mathrm{~g}$ for five minutes in the bronchoscopy suite. Centrifugation resulted in a $9.5 \%$ (SE $0.45 \%$ ) reduction in alveolar macrophage numbers. Differential cell counts were performed on cellular monolayers prepared in duplicate by cytocentrifugation of $5 \times 10^{4}$ cells $\left(50 \mu \mathrm{l}\right.$ of $10^{6}$ cells $\left./ \mathrm{ml}\right)$ at 450 $\mathrm{rev} / \mathrm{min}$ for 15 minutes (Shandon cytospin II). 
Slides were air dried for 30 minutes before being stained with May-Grünwald Giemsa stain. Five hundred cells were counted on each slide.

\section{PROTEIN AND UREA ASSAYS}

The urea assay was adapted from the UV-66 kit and the protein assay from the 610-A kit (Sigma Chemicals, Poole). The urea assay measured urea nitrogen and the sample to reagent ratio was adjusted to $1: 1$. The between assay coefficient of variation was $4.8 \%$ and the assay gave a linear curve over the range $0.001-$ $0.09 \mathrm{mmol} / 1$. The protein assay used Coomassie blue as the indicator and the sample to reagent ratio was 2:9. The coefficient of variation was $5.1 \%$ and the assay gave a linear curve over the range 0.002-0.010 g/l. Samples were diluted when values fell above the linear part of the curve. Protein and urea standards were prepared from quality controlled reference serum standards in a single batch and frozen at $-20^{\circ} \mathrm{C}$ until they were used. In each case standards were diluted with normal saline.

\section{STATISTICAL METHODS}

The reproducibility of microlavage was measured by calculating the coefficient of variation for the three measurements for each patient and taking the mean value. Differential cell counts were compared according to the method of Bland and Altman. ${ }^{10}$ Median calculated volumes of recovered lining fluid were compared by means of the Wilcoxon matched pairs test.
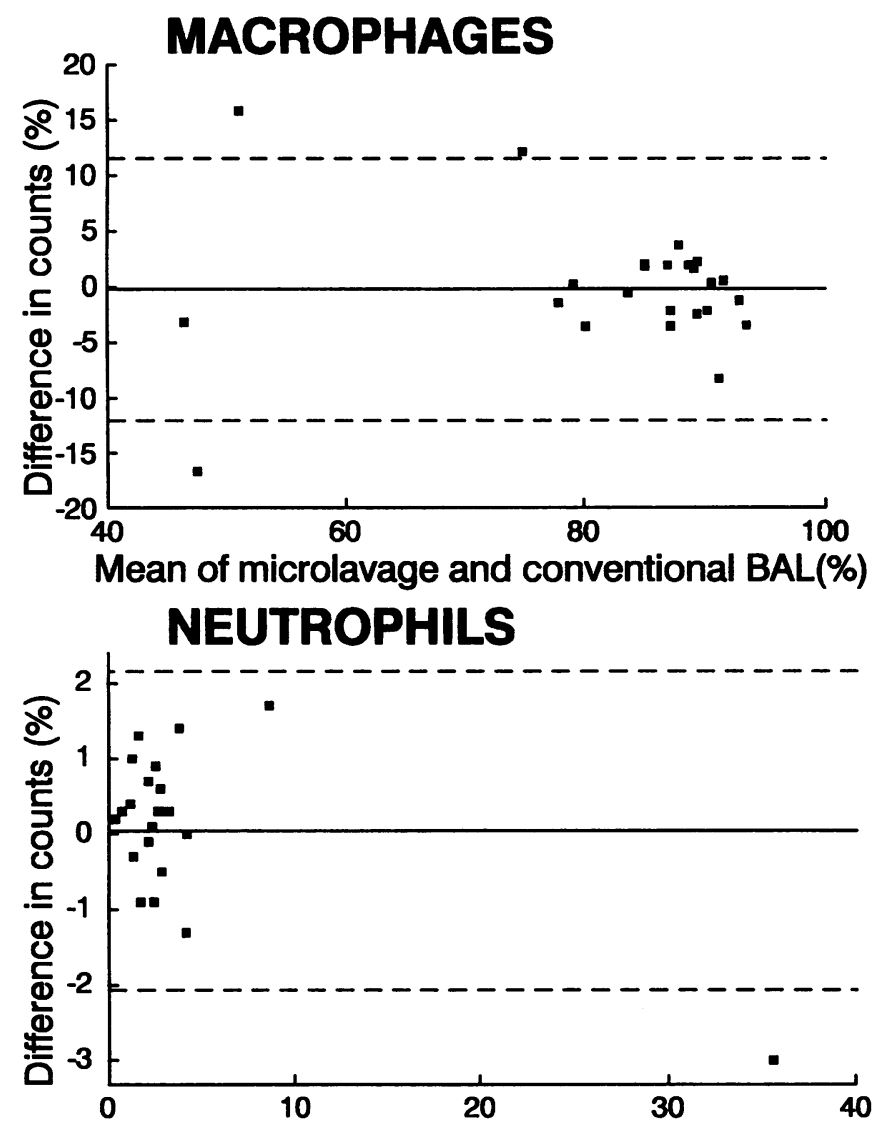

Mean of microlavage and conventional BAL(\%)

Comparison of differential cell counts (for neutrophils one difference was - microlavage); -.-.-.-- limits of agreement (means with 1.96 $\times$ SD).

\section{Results}

NECROPSY STUDY

All lung subsegments were filled with $18 \mathrm{ml}$ and 18 of the 20 subsegments studied were filled after $15 \mathrm{ml}$ had been instilled. Larger instilled volumes did not improve the yield of aspirated fluid. The injection time was less than 20 seconds. The best method of aspirating fluid was to withdraw the tube slightly with the airway under slight tension. Very gentle aspiration was required (less than $30 \mathrm{~mm} \mathrm{Hg}$ ).

\section{REPRODUCIBILITY}

Microlavage was well tolerated in all 15 patients but data from five were excluded because of blood staining of one or other sample. The remaining 10 patients had three values for total protein to urea concentration ratios (from three subsegments). Coefficients of variation for these three ratios ranged from $5 \cdot 7 \%$ to $14.5 \%$ with a mean of $9.0 \%$.

\section{COMPARISON OF DIFFERENTIAL CELL COUNTS WITH MICROLAVAGE AND CONVENTIONAL LAVAGE}

The extent of agreement between the results with microlavage and those with conventional lavage is shown in the figure. Differences between mean values are plotted against the mean of the counts obtained for each patient by the two techniques. ${ }^{10}$ Data from four patients were excluded because of contamination with blood. The median volume of aspirated fluid with the microlavage technique was $3.4 \mathrm{ml}$, which is much less than that of conventional lavage fluid

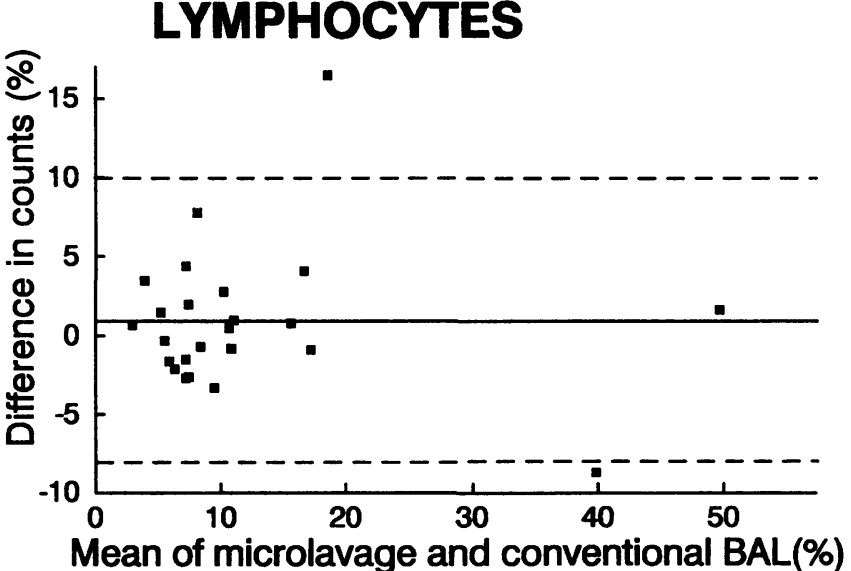
EOSINOPHILS

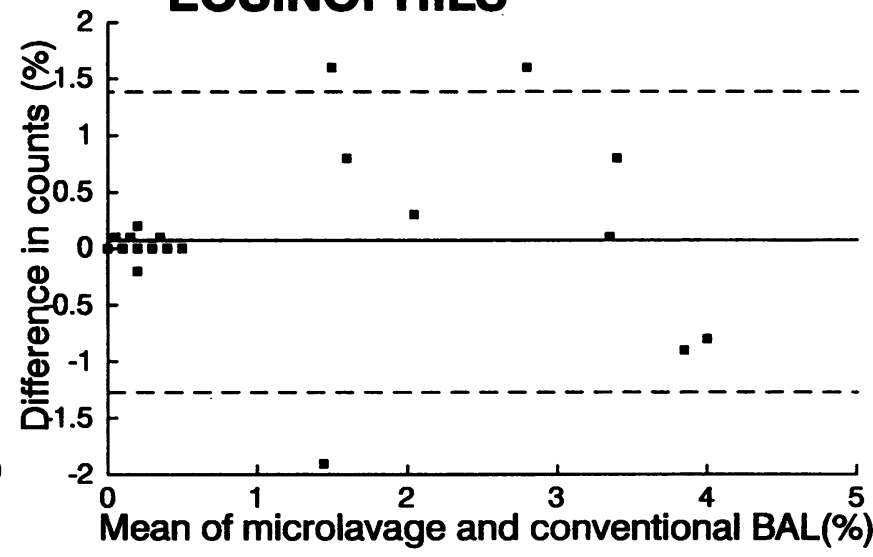


Comparison of microlavage with conventional lavage

\begin{tabular}{lll}
\hline & $\begin{array}{l}\text { Microlavage } \\
\text { Median (range) }\end{array}$ & $\begin{array}{l}\text { Conventional lavage } \\
\text { Median (range) }\end{array}$ \\
\hline Total cell count $\times 10^{6}$ & $0 \cdot 18(0.09-1 \cdot 1)$ & $18 \cdot 5(5 \cdot 2-70 \cdot 6)$ \\
Urea concentration $(\mathrm{mmol} / \mathrm{l})$ & $0.040(0 \cdot 008-0 \cdot 135)$ & $0.095(0.06-0 \cdot 142)$ \\
Total protein concentration $(\mathrm{g} / \mathrm{l})$ & $0 \cdot 046(0.005-0 \cdot 21)$ & $0.074(0 \cdot 024-0 \cdot 200)$ \\
Volume of recovered lavage fluid $(\mathrm{ml})$ & $3 \cdot 4(1 \cdot 8-5 \cdot 2)$ & $62 \cdot 8(27 \cdot 1-108)$ \\
\hline
\end{tabular}

(62.8 $\mathrm{ml}$ excluding the aspirate from the first $50 \mathrm{ml}$ aliquot-see table). In addition, the total cell count was far less.

\section{COMPARISON OF ESTIMATES OF EPITHELIAI LINING FLUID VOLUME}

On the basis of the protein concentration of the epithelial lining fluid derived from microlavage, the median volume of epithelial lining fluid recovered by conventional lavage was $1 \cdot 17 \%$ (range $0 \cdot 18-3 \cdot 34 \%$ ) of the aspirated volume. When the urea dilution method was applied to conventional lavage the epithelial lining fluid volume was calculated to be $1.52 \%(0.53-$ $4.06 \%$ ) (table). The difference between the median values was $0.42 \%$ (95\% confidence limits $0 \cdot 11 \%, 0 \cdot 79 \%$ ).

\section{Discussion}

The principal difficulty with the measurement of lining fluid constituents is the determination of epithelial lining fluid volume. ${ }^{711}$ Previous attempts have led to overestimates of this volume. Other workers have quantified constituents by expressing their concentration in relation to albumin or total protein, ${ }^{1-36}$ but these may also vary. ${ }^{1212}$ Studies looking at concentrations of urea, albumin, and protein recovered by successive lavage aliquots have shown a progressive increase in urea concentrations while total protein concentration remains stable. ${ }^{8}$ The increase in urea is due to its movement from blood to lavage fluid and therefore a lavage dwell time lasting less than one minute was suggested. ${ }^{813}$ In conventional lavage up to $200 \mathrm{ml}$ has to be instilled to reach alveoli and provide an adequate distal airway sample, ${ }^{912}$ but unfortunately this necessitates longer dwell times. Recent work has shown that even conventional lavage samples distal airway fluid rather than alveolar fluid, this fluid originating mainly from airways lined by respiratory epithelium. ${ }^{59}$

Smith and colleagues have shown that human airway surface protein profiles are similar with conventional lavage and with a peripheral lavage method using a Swan-Ganz catheter, but differ from those obtained with a "central" lavage technique. ${ }^{14}$ These findings are important because they suggest that a distal lavage technique samples the same lining fluid of the airways as conventional bronchoalveolar lavage. The peripheral lavage technique, similar to microlavage, samples the same lining fluid of the airways as conventional lavage. The microlavage technique is more likely to sample distal airway fluid as the tube is wedged into $2 \mathrm{~mm}$ diameter airways, and the necropsy study shows that it reaches the alveoli.
Microlavage takes less than 30 seconds to perform.

Initially we found that many of our samples had red cell counts greater than $4 \times 10^{5} / \mathrm{ml}$, and the yield of fluid was low. Care is needed when the tube is being wedged and the tube must be withdrawn slightly before aspiration to place the airway under slight tension to avoid kinking or collapse. Very low suction pressure is essential. When microlavage is repeated in different subsegments in the same patient the protein to urea ratio, the factor used to calculate lining fluid total protein concentration and hence epithelial lining fluid volume in conventional lavage aspirates, shows good reproducibility with a mean coefficient of variation of $9.0 \%$.

The overestimate of the volume of epithelial lining fluid obtained with the urea method with conventional lavage noted previously was confirmed, and also the wide variation in lining fluid total protein concentrations. The latter emphasises the need for quantitative measures of lining fluid constituents rather than qualitative estimates. ${ }^{14}$ The range of urea concentrations in lavage fluid was wide, largely as a result of two patients; one, with a small lining fluid volume, was probably dehydrated and the other, who had a large volume, had mild pulmonary oedema.

The results are consistent with the results of Marcy et $a l,{ }^{8}$ who obtained a lining fluid volume of $1 \%$ of the aspirated lavage fluid for a one minute dwell time. Recent work by Kelly et $a l^{13}$ has suggested that during lavage there are large fluxes of water across the alveolar-blood barrier resulting, in their experiments, in a net gain of water by the lavage fluid. This flux of water has an associated "solvent drag," which would cause movement of urea in proportion to its permeability coefficient. On the basis of this argument it has been estimated that the volume of lining fluid recovered by lavage should be no more than $0.2 \%$ of the aspirated fluid. ${ }^{15}$ There are several reasons why our results differ. Firstly, in calculating solvent drag we assumed from previous work in $\operatorname{dogs}^{16}$ that the permeability coefficient of urea was one twentieth of that of water. In the latter experiments, however, the permeability coefficient of water could not be calculated, but it was at least $400 \mathrm{~cm} / \mathrm{s} \times 10^{7}$ and could have been greater. If the permeability coefficient of water is much greater, this could explain the differences between our results and those estimated previously. ${ }^{1315}$ Secondly, water flux will be influenced greatly by the suction pressure applied. Our median recovered volume of lavage fluid was only $62.8 \mathrm{ml}$, compared with the $98 \mathrm{ml}$ of Kelly et $a l .{ }^{13}$ This implies a greater suction pressure in their experiment, and reflects our attempts to limit suction pressure and lavage dwell time. Thirdly, our conventional lavage procedure possibly sampled more proximal airway fluid, leading to a falsely high protein concentration, though lack of epithelial cells in the differential count preparations and the fact that the aspirate from our first aliquot was not included argue against this.

Recent work using animal models has en- 
abled more precise calculation of the movement of urea during lavage. ${ }^{17} 18$ In this model a 30 second lavage dwell time would produce a $15 \%$ overestimate of lining fluid volume. The time for instillation and aspiration in microlavage is 20 seconds, so an overestimate of lining fluid volume of less than $15 \%$ is likely. A percentage of epithelial lining fluid in the lavage fluid similar to ours was obtained in recent work in sheep using a rewash technique. ${ }^{19}$

The total cell counts in the microlavage sample are less than those in conventional lavage fluid $\left(0.19 v 15 \times 10^{6}\right)$. This means that the routine use of microlavage alone for sampling lining fluid and alveolar cells is not feasible, though it may provide a useful method of quantifying epithelial lining fluid volume, and may lead to more valid comparisons between control subjects and patients with disease.

1 Daniele RP, Elias JA, Epstein PE, Rossman MD. Bronchoalveolar lavage: role in the pathogenesis, diagnosis and management of interstitial lung disease. Ann Intern Med management of in

2 Hunninghake GW, Gadek JE, Kawanami O, Ferrans VJ, Crystal RG. Inflammatory and immune processes in the human lung in health and disease: evaluation by bronchoalveolar lavage. Am J Pathol 1979;97:149-204

3 Law RB, Davis GS, Giancola MS. Biochemical analyses of bronchoalveolar lavage fluids of healthy human volunteer smokers and non smokers. Am Rev Respir Dis 1978; 118:863-75.

4 Klech H, Pohl W, eds. Report of the European Society of Pneumonology Task Group on BAL. Technical recommendations and guidelines for bronchoalveolar lavage (BAL). Eur Respir J 1989;2:561-85.

5 Lam S, Leriche JC, Kijek K, Phillips D. Effect of bronchial lavage volume on cellular and protein recovery. Chest 1985;88:856-9.

6 Merrill WW, O'Hearn E, Rankin J, Naegel G, Matthay RA,
Reynolds HY. Kinetic analysis of the respiratory tract proteins recovered during a sequential lavage protocol. Am Rev Respir Dis 1982;126:617-20.

7 Rennard S, Basset G, Lecossier D, O'Donnell K, Martin P, Crystal RG. Estimation of volume of epithelial lining fluid recovered by lavage using urea as a marker of dilution. $J$ Appl Physiol 1986;60:532-8.

8 Marcy TW, Merrill WW, Rankin JA, Reynolds HY. Limitations of using urea to quantify epithelial lining fluid recovered by bronchoalveolar lavage. Am Rev Respir Dis 1987;135:1276-80.

9 Kelly CA, Kotre JC, Ware C, Hendrick DJ, Walters EH. Anatomical distribution of fluid at bronchoalveolar lavage. Thorax 1987;42:625-9.

10 Bland JM, Altman DG. Statistical methods for assessing agreement between two methods of clinical measurement. Lancet 1986;i:307-10.

11 Baughman RP, Bosken CH, London RG, Hantabise P, Wesseler $T$. Quantitation of bronchoalveolar lavage with methylene blue. Am Rev Respir Dis 1983;128:266-70.

12 Rennard S, Ghafouri MO, Thompson AB, Linder J, Vaughan $\mathrm{W}$, Jones $\mathrm{K}$, et al. Fractional processing of sequential bronchoalveolar lavage to separate bronchial and alveolar samples. Am J Respir Dis 1990;141:208-17.

13 Kelly CA, Fenwick JD, Corris PA, Fleetwood A, Hendrick DJ, Walters EH. Fluid dynamics during bronchoalveolar lavage. Am Rev Respir Dis 1988;138:81-4.

14 Smith SF, Guz A, Winning AJ, Cooke NT, Burton GH, Tetley TP. Comparison of human lung surface protein profiles from the central and peripheral airways sampled using two regional lavage techniques. Eur Respir $J$ 1988;1:792-800.

15 Duddridge $M$, Fenwick JD, Ward C, Hendrick DJ, Walters EH. Urea as a marker for the epithelial lining fluid volume sampled by bronchoalveolar lavage [abstract]. Thorax 1989;44:872P.

16 Taylor AE, Guyton AC, Bishop US. Permeability of the alveolar membrane to solutes. Circ Res 1965;16:353-61.

17 Effros RM, Mason GR, Silverman P, Reid E, Hukkanen J. Movement of ions and small solutes across endothelium and epithelium of perfused rabbit lungs. J Appl Physiol 1986;60:100-7.

18 Effros RM, Mason GR, Sietsema K, Hukkanen J, Silverman P. Pulmonary epithelial sieving of small solutes in rat lungs. J Appl Physiol 1988;65:640-8.

19 Peterson BT, Idell S, Macarthur C, Gray LD, Cohen AB. A modified bronchoalveolar lavage procedure that allows measurement of lung epithelial lining fluid volume. $A m$ Rev Respir Dis 1990;141:314-20. 